\title{
Persistence of coral assemblages at East and West Flower Garden Banks, Gulf of Mexico
}

\author{
Michelle A. Johnston ${ }^{1} \cdot$ John A. Embesi $^{1} \cdot$ Ryan J. Eckert $^{1} \cdot$ Marissa F. Nuttall $^{1}$ \\ Emma L. Hickerson ${ }^{1} \cdot$ George P. Schmahl ${ }^{1}$
}

Received: 16 October 2015/Accepted: 19 April 2016/Published online: 29 April 2016

(c) The Author(s) 2016. This article is published with open access at Springerlink.com

\begin{abstract}
Since 1989 a federally supported long-term coral reef monitoring program has focused on two study sites atop East and West Flower Garden Banks in the northwestern Gulf of Mexico. We examined $25 \mathrm{yr}$ of benthic cover data to provide a multi-decadal baseline and trend analysis of the community structure for this coral reef system. Despite global coral reef decline in recent decades, mean coral cover at East and West Flower Garden Banks was above $50 \%$ for the combined $25 \mathrm{yr}$ of continuous monitoring, and represented a stable coral community. However, mean macroalgal cover increased significantly between 1998 and 1999, rising from approximately 3 to $20 \%$, and reaching a maximum above $30 \%$ in 2012 . In contrast to many other shallow water reefs in the Caribbean region, increases in mean macroalgal cover have not been concomitant with coral cover decline at the Flower Garden Banks.
\end{abstract}

Keywords Coral · Flower Garden Banks National Marine Sanctuary · Gulf of Mexico · Monitoring

\section{Introduction}

East and West Flower Garden Banks (EFGB and WFGB) are part of a series of coral reefs and coral communities along the outer continental shelf in the northwestern Gulf

Communicated by Ecology Editor Dr. Stuart A. Sandin

Michelle A. Johnston

michelle.a.johnston@noaa.gov

1 NOAA Office of National Marine Sanctuaries, Flower Garden Banks National Marine Sanctuary, 4700 Avenue U, Bldg. 216, Galveston, TX 77551, USA of Mexico (Bright et al. 1985). These habitats provide favorable conditions for hermatypic corals and support abundant fish and invertebrate populations (Clark et al. 2014; Johnston et al. 2015). In 1989, the United States Department of the Interior established a long-term coral reef monitoring program at EFGB and WFGB to monitor for potential impacts from nearby oil and gas development. In 1992, EFGB and WFGB were designated as Flower Garden Banks National Marine Sanctuary, and Stetson Bank was later added in 1996. The purpose of this study was to examine $25 \mathrm{yr}$ of benthic cover data at EFGB and WFGB and provide a multi-decadal baseline and trend analysis of the community structure of this unique coral reef that continues to flourish when many other reefs in the Atlantic and Caribbean region are declining due to environmental and anthropogenic stressors (Gardner et al. 2003; Mumby and Steneck 2011; DeBose et al. 2012; Jackson et al. 2014).

\section{Materials and methods}

EFGB and WFGB are located approximately $190 \mathrm{~km}$ south of the Texas and Louisiana border, with a variety of habitats ranging in depth from $17-140 \mathrm{~m}$ (Fig. 1). The shallowest portions of each bank are topped by well-developed coral reefs, in depths ranging $17-50 \mathrm{~m}$. Benthic percentage cover data have been collected annually during summer months since 1989 at permanent $10,000 \mathrm{~m}^{2}$ study sites (hereafter referred to as "study sites") on each bank (Fig. 2). Within the study sites, depths ranged $17-27 \mathrm{~m}$.

Benthic cover was determined through analysis of a series of non-overlapping randomly located $10-\mathrm{m}$ phototransects. Like many long-term monitoring programs, a variety of underwater camera setups was used to capture 


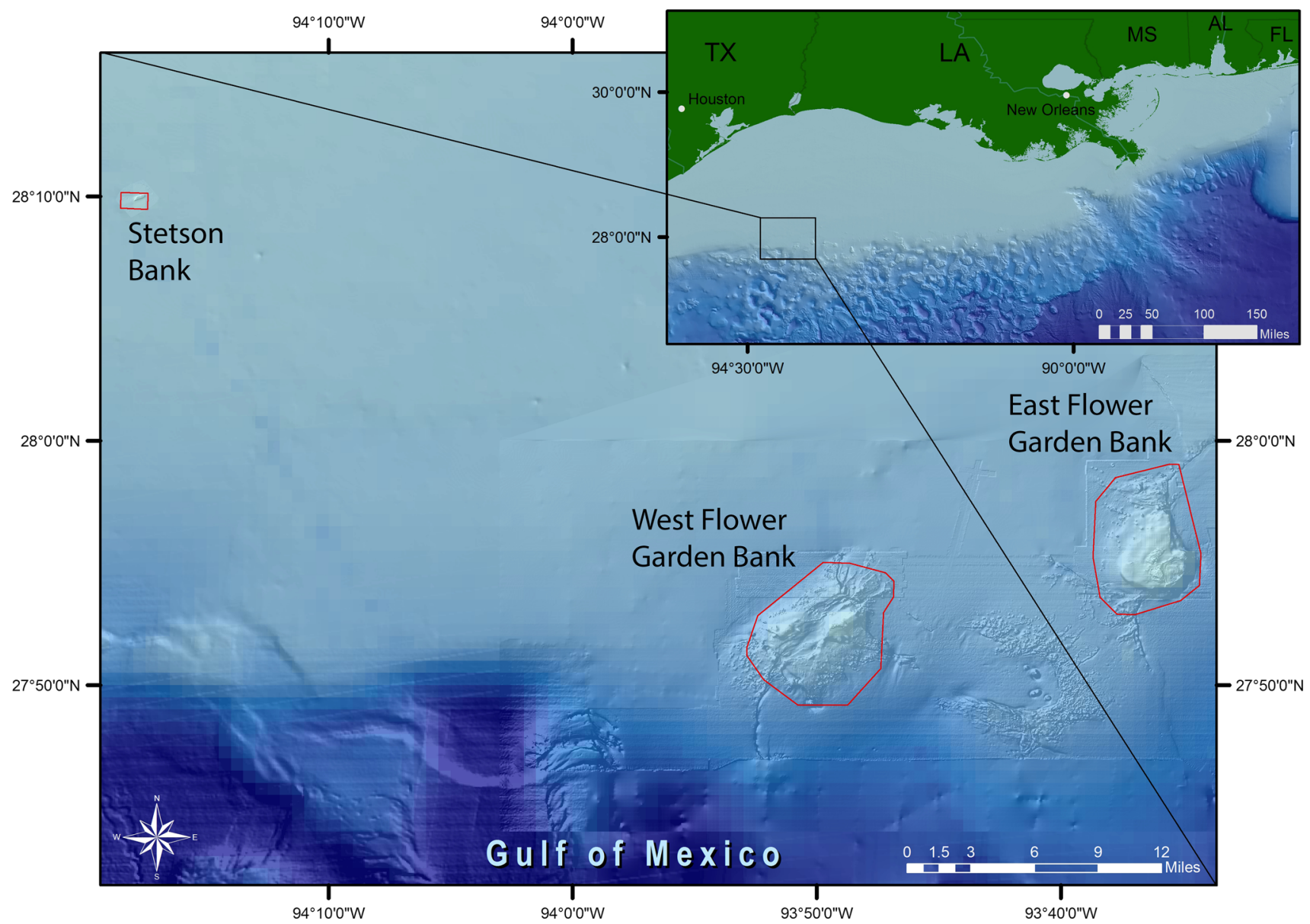

Fig. 1 Bathymetric map of outlined Flower Garden Banks National Marine Sanctuary boundaries, consisting of Stetson Bank (2.18 km²), East Flower Garden Bank $\left(65.86 \mathrm{~km}^{2}\right)$, and West Flower Garden Bank $\left(77.54 \mathrm{~km}^{2}\right)$, located on the outer Texas-Louisiana continental shelf (inset)

benthic cover as technology advanced from 35-mm slides (1989-2001), digital videography using video still frame grabs (2002-2009), and digital still images (2010-2014) (Gittings et al. 1992; CSA 1996; Dokken et al. 1999, 2003; Precht et al. 2006; Zimmer et al. 2010; Johnston et al. 2015). Currently, a Canon Power Shot G11 digital camera in an Ikelite housing and 28-mm equivalent wet mount lens adaptor, mounted on a $0.65-\mathrm{m} \mathrm{t}$-frame with bubble level and two Inon Z240 strobes is used to capture images along 16 transects per study site. The mounted camera was placed at intervals marked on a spooled measuring tape at $80 \mathrm{~cm}$ apart producing 17 non-overlapping images along the transect.

Since 2004, mean percent benthic cover has been analyzed using Coral Point Count with Microsoft Excel extensions (CPCe) versions 3.3 and 4.1 with a 500 point overlay distributed among all images within a transect (Aronson et al. 1994; Kohler and Gill 2006). Organisms positioned beneath each random point were identified to the lowest possible taxonomic level and grouped into four primary functional groups: (1) coral; (2) sponge; (3) macroalgae; and (4) "CTB," a composite substrate category that includes crustose coralline algae, fine turf algae, and bare rock (Aronson and Precht 2000; Aronson et al. 2005). Macroalgae included algae longer than approximately $3 \mathrm{~mm}$ and thick algal turfs. Point counts were analyzed for photos within a transect, and mean percentage cover was determined for all groups by averaging all transects per bank. Prior to the use of $\mathrm{CPCe}$, percent cover was calculated with myler traces and a calibrated planimeter from 1989 to 1995 (Gittings et al. 1992; CSA 1996). From 1996 to 2003, random dot layers were generated manually in photo software programs (Dokken et al. 1999, 2003).

The range of data collected has varied slightly over the years. From 1989 to 1991, only mean percentage coral cover was collected; other major functional groups were added in 1992. No data were collected in 1993 due to poor weather. Significant long-term trends in mean percentage cover were detected using the Mann-Kendall trend test in R version 3.2.0 (Hipel and McLeod 1994). Functional group means by year and bank were compared using 


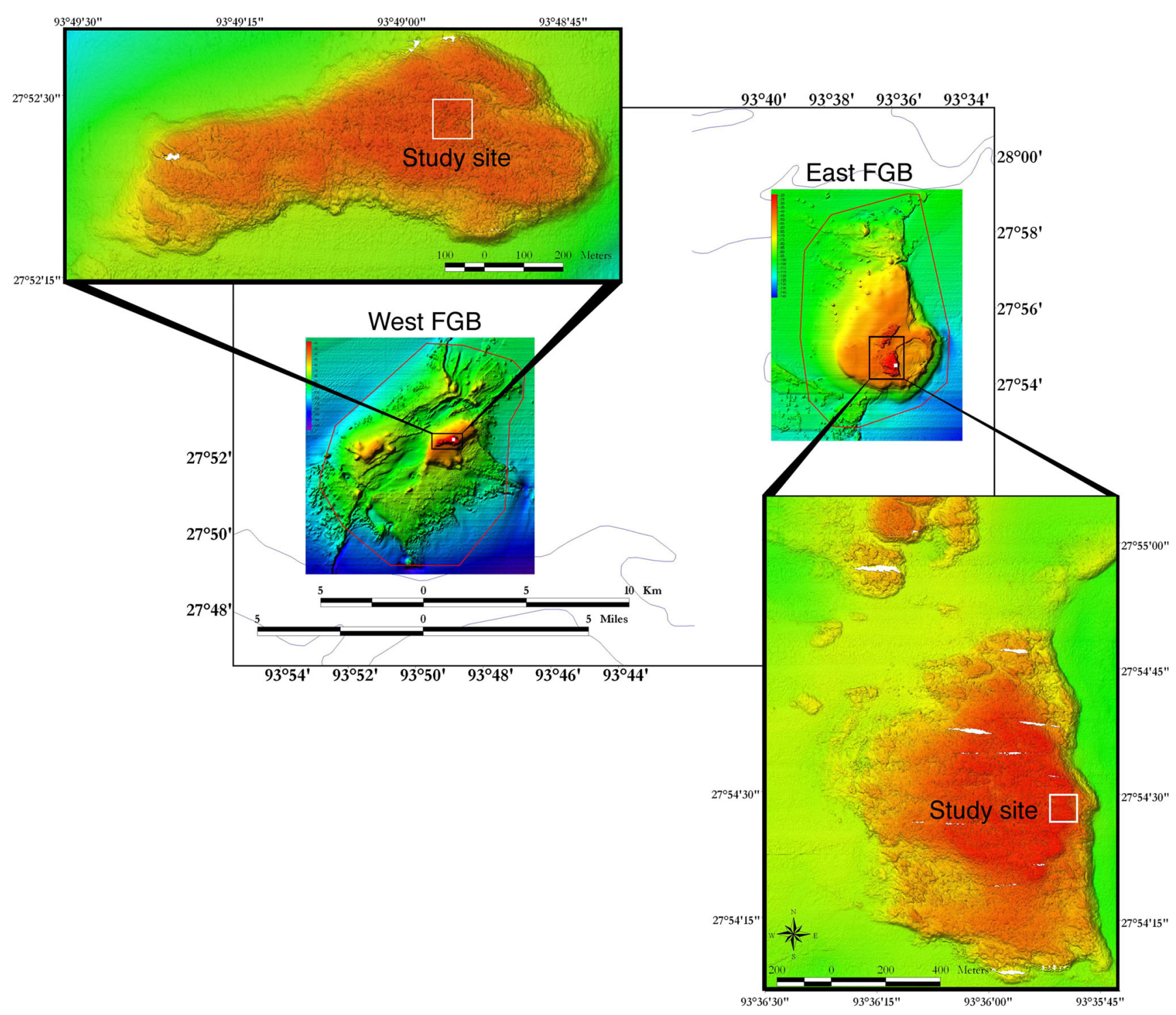

Fig. 2 Bathymetric map showing the study sites at both banks. The areas in red are generally those that are shallow enough to support coral reef growth

multidimensional scaling with a time series trajectory in Primer version 6.0 (Anderson et al. 2008). Cluster analyses were performed on Bray-Curtis similarity matrices with SIMPROF tests to identify significant $(\alpha=0.05)$ clusters within the data. Significant community differences were identified using ANOSIM (Clarke and Warwick 2001; Anderson et al. 2008).

\section{Results and discussion}

Mean coral cover at EFGB and WFGB during the period 1989-2014 ranged 39-62\%, significantly increasing over time $(\tau=0.571, p<0.001)$ (Fig. 3). Dominant coral species with the greatest mean percent cover were the Orbicella species group (31.8\%) (primarily Orbicella franksi), followed by Pseudodiploria strigosa (8.4\%) (Fig. 4). There were no significant differences in coral species composition between banks from 1989 to 2014. Macroalgae and CTB cover generally varied inversely, with macroalgae significantly increasing $(\tau=0.648, p<0.001)$ and CTB significantly decreasing $(\tau=-0.552, p<0.001)$ over time (Fig. 3). ANOSIM results comparing the bank communities revealed no significant dissimilarities, suggesting that EFGB and WFGB were similar to each other in overall benthic community composition from 1989-2014.

Prior to 1999, macroalgal cover was consistently below 3\%; however, in 1999, macroalgal cover increased to approximately $20 \%$ and has remained high ever since (peaking above 30\% in 2012 and remaining near 30\% since 2013). Multivariate historical percent cover analysis was compared among years for which appropriate data was 
Fig. 3 Mean percentage cover of coral (red triangles), macroalgae (green circles), crustose coralline algae/turf/ bare rock (CTB, gray squares) and sponges (orange diamonds) at (a) East Flower Garden Bank and (b) West Flower Garden Bank. Error bars are standard errors (not available before 1996). Data from Gittings et al. (1992); CSA (1996); Dokken et al. (2003); Precht et al. (2006, 2008); Johnston et al. (2013, 2015)
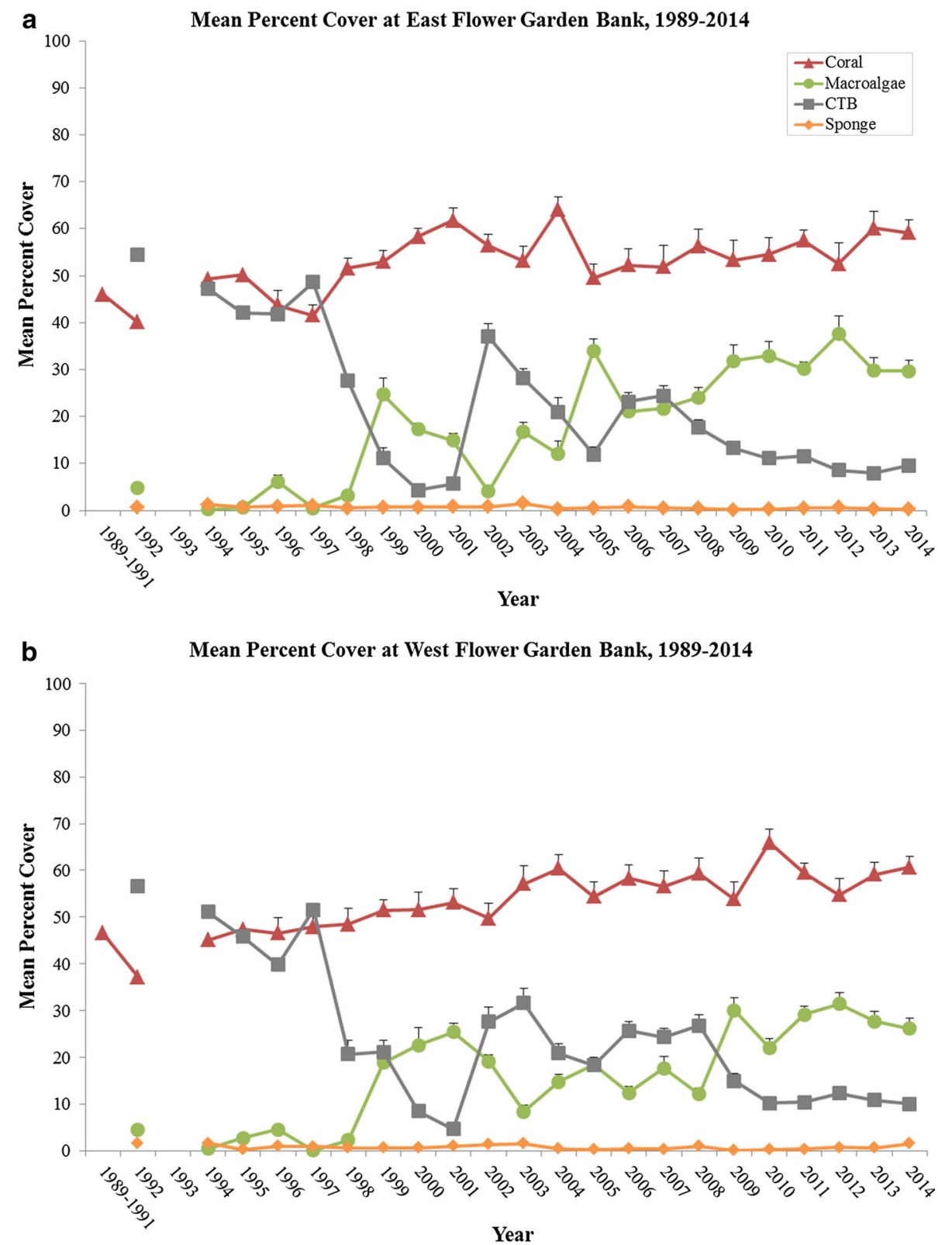

available (1994-2014) to evaluate benthic cover change over time. SIMPROF tests from cluster analysis resulted in two significant $(\pi=3.290, p<0.001)$ clusters $(85 \%$ similar) corresponding to the shift in increased macroalgae. In the cluster defined by the years 1999-2014, a smaller variation of two non-significant clusters (90\% similar) was also identified, one generally for the period 2002-2008, and the other for the period 2009-2014 (Fig. 5).

An inverse relationship between macroalgae and CTB has been observed throughout the monitoring program. However, after 2008, macroalgal cover was greater than CTB cover, continuing to increase until 2012. These trends suggest that from 1994 to 1998 the reef community was stable but there was a shift beginning in 1999 as CTB

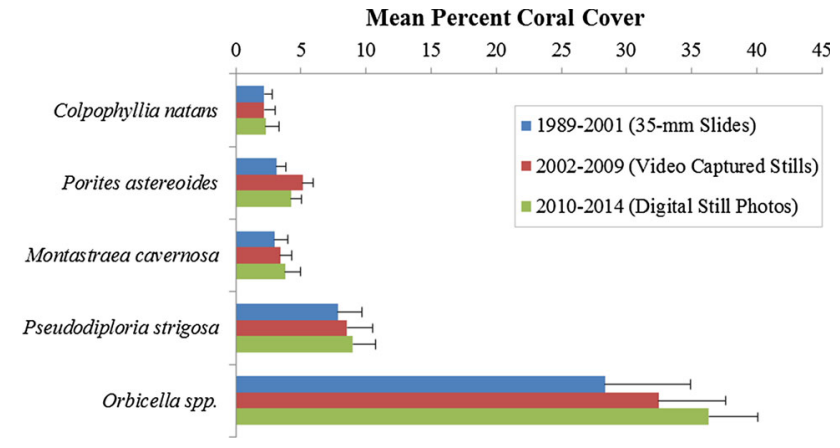

Fig. 4 Percentage cover of dominant coral species at East Flower Garden Bank and West Flower Garden Bank 1989-2014. The Orbicella species group combines $O$. franksi, O. faveolata, and $O$. annularis. These species have been recognized as separate in recent years, but are grouped to compare historical data 
Fig. 5 MDS plot based on Bray-Curtis similarities comparing mean benthic cover 1994-2014 at East Flower Garden Bank and West Flower Garden Bank. The green circles group years that are $85 \%$ similar, and the purple circles group years that are $90 \%$ similar

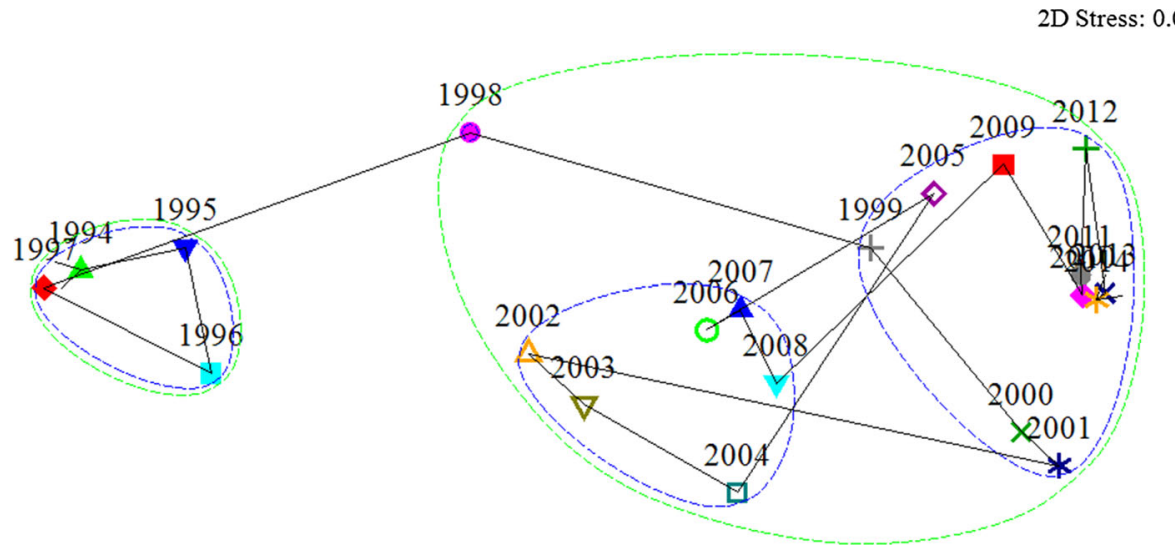

declined and macroalgae cover increased, causing the community to change due to significantly higher macroalgal cover.

This shift in macroalgal cover is consistent with other reefs in the Gulf of Mexico and Caribbean region. Nearby Stetson Bank, located $48 \mathrm{~km}$ northwest of WFGB, is a series of claystone and siltstone pinnacles covered by a diverse coral and sponge community, which has shown a similar but more pronounced trend (DeBose et al. 2012). Prior to 1999 mean coral cover on high relief pinnacles at Stetson Bank ranged 23-32\%, mean sponge cover ranged $27-39 \%$, and mean macroalgal cover ranged 13-20\%. After 1999, coral and sponge cover decreased to 7 and $16 \%$, respectively, while macroalgal cover increased to $62 \%$, presumably from river discharge flowing offshore, hurricanes, and thermal stress leading to bleaching events (DeBose et al. 2012). Toth et al. (2014) reported increased macroalgae cover and significant coral decline from 1998 to 2012 at study sites in Florida Keys National Marine Sanctuary where mean coral cover had declined to $2 \%$ by 2011, likely due to disease, hurricane damage, and thermal stress. Other reefs in the wider Caribbean region are also showing declines largely due to algal competition, overfishing, bleaching, and coral disease (Gardner et al. 2003; Steneck and Lang 2003; Jackson et al. 2014).

In contrast, EFGB and WFGB have not shown a decline in coral cover, despite periodic hurricanes and bleaching events (Hagman and Gittings 1992; Dudgeon et al. 2010). Some possible reasons for the relatively stable condition of the banks include: (1) deep water $(17-25 \mathrm{~m})$ that provides a more stable environment than shallow reefs; (2) the remote offshore location (190 km offshore), limiting anthropogenic stressors from coastal runoff; (3) oligotrophic oceanic conditions; and (4) protective federal regulations (Aronson et al. 2005; Johnston et al. 2015). It should be noted the FGB coral community lacks acroporid corals that have contributed to regional decline in coral cover (Aronson et al. 2005).
Despite their remoteness, EFGB and WFGB are not immune to impacts. Climate change, invasive species, storms, and water quality degradation are potential threats (ONMS 2008; Nuttall et al. 2014). As the Gulf of Mexico ecosystem continues to change (Karnauskas et al. 2015), ongoing monitoring will be critical to document ecosystem variation. The relatively high coral cover since the beginning of the monitoring program make EFGB and WGB ideal for protection and conservation. Continued monitoring will document changes in the reef community condition compared to the historical baseline and enable resource managers to make decisions regarding management and research activities focused on the dynamics of the benthic communities and the biota they support.

Acknowledgments We thank the United States Department of the Interior's Bureau of Ocean Energy Management (BOEM), as well as scientific divers from Texas A\&M University-Galveston, the crews of the RV Manta, MV Fling and MV Spree, and previous researchers including T. Bright, S. Gittings, G. Boland, Q. Dokken, teams from Texas A\&M University, Continental Shelf Associates, Inc., and PBS\&J. We also thank the anonymous referees for their insightful comments. This study was funded through an interagency agreement between BOEM and the FGBNMS under contract numbers M09PG00011 and M14PG00020. Field work was carried out under permits: FGBNMS-2014-001, FGBNMS-2009-001, FGBNMS-2004001, FGBNMS-2007-008.

Open Access This article is distributed under the terms of the Creative Commons Attribution 4.0 International License (http://crea tivecommons.org/licenses/by/4.0/), which permits unrestricted use, distribution, and reproduction in any medium, provided you give appropriate credit to the original author(s) and the source, provide a link to the Creative Commons license, and indicate if changes were made.

\section{References}

Anderson MJ, Gorley RN, Clarke KR (2008) PERMANOVA+ for PRIMER: guide to software and statistical methods. PRIMER-E Ltd., Plymouth, United Kingdom 
Aronson RB, Precht WF (2000) Herbivory and algal dynamics on the coral reef at Discovery Bay, Jamaica. Limnol Oceanogr 45:251-255

Aronson RB, Precht WF, Murdoch TJ, Robbart ML (2005) Long-term persistence of coral assemblages on the Flower Garden Banks, northwestern Gulf of Mexico: implications for science and management. Gulf Mex Sci 23:84-94

Aronson RB, Edmunds PJ, Precht WF, Swanson DW, Levitan DR (1994) Large-scale, long-term monitoring of Caribbean coral reefs: simple, quick, inexpensive methods. Atoll Res Bull 421:1-19

Bright TJ, McGrail DW, Rezak R, Boland GS, Trippett AR (1985) The Flower Gardens: a compendium of information. OCS Study MMS 85-0024, US Department of the Interior, Minerals Management Service, Gulf of Mexico OCS Region, New Orleans, Louisiana

Clark R, Taylor JC, Buckel CA, Kracklet LM (eds) (2014) Fish and benthic communities of the Flower Garden Banks National Marine Sanctuary: science to support sanctuary management. National Oceanic and Atmospheric Administration Technical Memorandum NOS NCCOS 179, Silver Spring, MD

Clarke KR, Warwick RM (2001) Changes in marine communities: an approach to statistical analysis and interpretation. Plymouth Marine Laboratory, Plymouth, United Kingdom

CSA (Continental Shelf Associates) (1996) Long-term monitoring at the East and West Flower Garden Banks. OCS Study MMS 96-0046, US Department of the Interior, Minerals Management Service, Gulf of Mexico OCS Region, New Orleans, Louisiana

DeBose JL, Nuttall MF, Hickerson EL, Schmahl GP (2012) A highlatitude coral community with an uncertain future: Stetson Bank, northwestern Gulf of Mexico. Coral Reefs 32:255-267

Dudgeon SR, Aronson RB, Bruno JF, Precht WF (2010) Phase shifts and stable states on coral reefs. Mar Ecol Prog Ser 413:201-216

Dokken QR, MacDonald IR, Tunnell JW Jr, Beaver CR, Boland GS, Hagman DK (1999) Long-term monitoring of the East and West Flower Garden Banks 1996-1997. OCS Study MMS 99-0005, US Department of the Interior, Minerals Management Service, Gulf of Mexico OCS Region, New Orleans, Louisiana

Dokken QR, MacDonald IR, Tunnell JW Jr, Wade T, Withers K, Dilworth SJ, Bates TW, Beaver CR, Rigaud CM (2003) Longterm monitoring at the East and West Flower Garden Banks National Marine Sanctuary, 1998-2001. OCS Study MMS 2003-031, US Department of the Interior, Minerals Management Service, Gulf of Mexico OCS Region, New Orleans, Louisiana

Gardner TA, Côté IM, Gill JA, Grant A, Watkinson AR (2003) Longterm region-wide declines in Caribbean corals. Science 301:958-960

Gittings SR, Boland GS, Deslarzes KJP, Hagman DK, Holland BS (1992) Long-term monitoring at the East and West Flower Garden Banks. OCS Study MMS 92-0006, US Department of the Interior, Minerals Management Service, Gulf of Mexico OCS Region, New Orleans, Louisiana

Hagman DK and Gittings SR (1992) Coral bleaching on high latitude reefs at the Flower Garden Banks, NW Gulf of Mexico. Proc 7th Int Coral Reef Symp 1:38-43

Hipel KW, McLeod AI (1994) Time series modelling of water resources and environmental systems. http://www.stats.uwo.ca/ faculty/aim/RPackages.htm

Jackson JBC, Donovan MK, Cramer KL, Lam VV (eds) (2014) Status and trends of Caribbean coral reefs: 1970-2012. Global Coral Reef Monitoring Network, IUCN, Gland, Switzerland

Johnston MA, Nuttall MF, Eckert RJ, Embesi JA, Slowey NC, Hickerson EL, Schmahl GP (2013) Long-term monitoring at the
East and West Flower Garden Banks National Marine Sanctuary, 2009-2010: volume I: technical report. OCS Study BOEM 2013-0214, US Department of the Interior, Bureau of Ocean Energy Management, Gulf of Mexico OCS Region, New Orleans, Louisiana

Johnston MA, Nuttall MF, Eckert RJ, Embesi JA, Slowey NC, Hickerson EL, Schmahl GP (2015) Long-term monitoring at the East and West Flower Garden Banks National Marine Sanctuary, 2011-2012: volume I: technical report. OCS Study BOEM 2015-0194, US Department of the Interior, Bureau of Ocean Energy Management, Gulf of Mexico OCS Region, New Orleans, Louisiana

Karnauskas M, Schirripa MJ, Craig JK, Cook GS, Kelble CR, Agar JJ, Black BA, Enfield DB, Lindo-Atichati D, Muhling BA, Purcell KM, Richards PM, Wang C (2015) Evidence of climatedriven ecosystem reorganization in the Gulf of Mexico. Glob Chang Biol 21:2554-2568

Kohler K, Gill SM (2006) Coral point count with excel extensions (CPCe): a visual basic program for the determination of coral and substrate coverage using random point count methodology. Comput Geosci 32:1259-1269

Mumby PJ, Steneck RS (2011) The resilience of coral reefs and its implications for reef management. In: Dubinsky Z, Stambler N (eds) Coral reefs: an ecosystem in transition. Springer, Netherlands, pp 509-519

Nuttall MF, Johnston MA, Eckert RJ, Embesi JA, Hickerson EL, Schmahl GP (2014) Lionfish (Pterois volitans [Linnaeus, 1758] and $P$. miles [Bennett, 1828]) records within mesophotic depth ranges on natural banks in the Northwestern Gulf of Mexico. Bioinvasions Rec 3:111-115

ONMS (Office of National Marine Sanctuaries) (2008) Flower Garden Banks National Marine Sanctuary condition report 2008. US Department of Commerce, National Oceanic and Atmospheric Administration, Office of National Marine Sanctuaries, Silver Spring, Maryland

Precht WF, Aronson RB, Deslarzes KJP, Robbart ML, Evans DJ, Zimmer B, Duncan L (2008) Long-term monitoring at the East and West Flower Garden Banks, 2004-2005 interim report: volume I: Technical report. OCS Study MMS 2008-027, US Department of the Interior, Minerals Management Service, Gulf of Mexico OCS Region, New Orleans, Louisiana

Precht WF, Aronson RB, Deslarzes KJP, Robbart ML, Gelber A, Evans D, Gearheart B, Zimmer B (2006) Long-term monitoring at the East and West Flower Garden Banks, 2002-2003: final report. OCS Study MMS 2004-031, US Department of the Interior, Minerals Management Service, Gulf of Mexico OCS Region, New Orleans, Louisiana

Steneck RS, Lang JC (2003) Rapid assessment of Mexico's Yucatan reef in 1997 and 1999: pre- and post-1988 mass bleaching and Hurricane Mitch. Atoll Res Bull 496:294-317

Toth LT, van Woesik R, Murdocj TJT, Smith SR, Ogden JC, Precht WF, Aronson RB (2014) Do no-take reserves benefit Florida's corals? 14 years of change and stasis in the Florida Keys National Marine Sanctuary. Coral Reefs 33:565-577

Zimmer B, Duncan L, Aronson RB, Deslarzes KJP, Deis D, Robbart ML, Precht WF, Kaufman L, Shank B, Weil E, Field J, Evans DJ, Whaylen L (2010) Long-term monitoring at the East and West Flower Garden Banks, 2004-2008: volume I: Technical report. OCS Study BOEMRE 2010-052, US Department of the Interior, Bureau of Ocean Energy Management, Regulation, and Enforcement, Gulf of Mexico OCS Region, New Orleans, Louisiana 